\title{
ANALISIS HUKUM BAGI PEKERJA YANG MENOLAK VAKSINASI COVID-19 DI INDONESIA
}

\author{
Jefri Hari Akbar*, Yusriyadi, Soeganda Priyatna \\ Program Studi Doktor Hukum \\ Fakultas Hukum Universitas Diponegoro \\ J1. Imam Bardjo, S.H. No. 1, Semarang \\ jenari88@gmail.com
}

\begin{abstract}
Indonesia has announced a state of medical emergency through Presidential Decree No. 11 Year 2020 regarding Covid-19. Vaccination is one of government's effort to increase people's immunity. Industrial clusters are one of the hotspots contributing to Covid-19 cases. The Ministry of Health made Vaccine Gotong Royong policy. This paper discusses the legal analysis and roles of legal entities or companies on dealing employee who refused to get vaccinated. This paper use normative research methods with the use of legal and conceptual approach. In conclusion, vaccination for employees during a pandemic is not a right but an obligation, companies need to understand their position regarding the regulation of employees vaccination, so that companies can educate and impose sanctions to employees who refused to get vaccinated.
\end{abstract}

Keywords: Workers; Vaccinations; Coronavirus Disease.

\begin{abstract}
Abstrak
Indonesia telah mengumumkan status kedaruratan kesehatan melalui Keputusan Presiden Nomor 11 Tahun 2020 akibat pandemi Covid-19. Vaksinasi merupakan salah satu upaya yang dilakukan untuk meningkatkan kekebalan tubuh masyarakat. Klaster industri merupakan salah satu titik rawan penambahan pasien Covid-19. Kementerian Kesehatan telah membuat kebijakan program vaksin gotong royong. Tulisan ini membahas perihal analisis hukum bagi pekerja yang menolak vaksinasi Covid-19, serta bagaimana peran badan hukum/pengusaha terkait adanya pekerja yang menolak untuk divaksinasi. Kajian ini menggunakan metode normatif dengan menggunakan pendekatan perundang-undangan serta pendekatan konseptual. Kesimpulannya adalah vaksinasi untuk pekerja dalam kondisi darurat bukanlah hak namun merupakan kewajiban, pengusaha perlu memahami kedudukan regulasi perundangan terkait pengaturan vaksinasi bagi pekerja, sehingga dapat memberikan edukasi serta memberlakukan sanksi bagi pekerja yang tidak mau divaksinasi.
\end{abstract}

Kata Kunci: Pekerja; Vaksinasi; Coronavirus Disease.

\section{A. Pendahuluan}

Wabah Corona Virus Disease 2019 (Covid-19) yang menyebar di dunia pada tahun 2020 menyebabkan kedaruratan di hampir semua negara, termasuk Indonesia. Awalnya penyakit ini disebut sebagai 2019 Novel Coronavirus (2019-nCoV), kemudian WHO pada tanggal 11 
Februari 2020 mengumumkan nama baru yaitu Coronavirus Disease (COVID-19) yang disebabkan virus Severe Acute Respiratory Syndrome Coronavirus-2 (SARS-CoV-2). Temuan kasus pertama pneumonia misterius terjadi pada Desember 2019 dilaporkan di Wuhan Provinsi Hubei dimana sumber penularan kasus ini masih belum dapat diketahui pasti, namun dikaitkan dengan pasar ikan di Wuhan (Rothan \& Byrareddy, 2020).

Jalannya perekonomian dunia sebagian besar bergantung pada kerjasama dengan Cina dimana Cina sebagai sumber utama permintaan komoditas maupun bahan baku produksi. Apabila Cina menghentikan segala aktivitas perekonomian akibat pandemi Covid-19, maka akan sangat berdampak pada jalannya perekonomian di banyak negara (Acikgoz \& Gunay, 2020).

Covid-19 menyebabkan perekonomian dunia menjadi terpuruk, dikarenakan penyebaran Covid-19 mengubah pola hidup masyarakat untuk menjaga jarak satu sama lain, serta pembatasan jumlah orang dalam satu ruangan. Hal ini menyebabkan banyak sektor industri maupun perkantoran membatasi jumlah pekerjanya yang masuk sehingga produktivitasnya menurun. Selain itu beberapa dampak yang terjadi seperti tidak berjalannya operasional perusahaan baik secara sementara ataupun permanen, banyak pekerja yang gajinya dipotong, dirumahkan, hingga pemutusan hubungan kerja (PHK). Penyebaran Covid-19 ini menyebabkan ketidakpastian dalam hal investasi ekonomi dan pasar konsumen (Ozili \& Arun, 2020). Sisi lain sebagian besar negara yang memilih untuk menerapkan lockdown untuk mencegah penyebaran Covid-19 tidak mempertimbangkan dampak penerapan lockdown terhadap rantai pasokan global (Guan وآخ . 2020).

Pada kondisi pandemi Covid-19 pemerintah Indonesia bergerak cepat dengan menerbitkan Keputusan Presiden No. 11 Tahun 2020 Tentang Penetapan Kedaruratan Kesehatan Masyarakat Corona Virus Disease 2019 (Covid-19), yang juga diikuti dengan terbitnya Peraturan Pemerintah Pengganti Undang-Undang No. 1 Tahun 2020 Tentang Kebijakan Keuangan Negara dan Stabilitas Sistem Keuangan Untuk Penanganan Pandemi Corona Virus Disease 2009 (Covid-19) dan/atau Dalam Rangka Menghadapi Ancaman Yang Membahayakan Perekonomian Nasional dan/atau Stabilitas Sistem Keuangan, serta Peraturan Pemerintah No. 21 Tahun 2020 Tentang Pembatasan Sosial Berskala Besar Dalam Rangka Percepatan Penanganan Corona Virus Disease 2019 (Covid-19).

Dalam rangka percepatan vaksinasi kepada seluruh masyarakat, Kementerian Kesehatan membuat program vaksinasi gotong royong dengan dasar hukum Peraturan Menteri Kesehatan Nomor 19 Tahun 2021 Tentang Perubahan Atas Permenkes Nomor 10 Tahun 2021 Tentang Pelaksanaan Vaksinasi dalam Rangka Penanggulangan Pandemi Covid-19 untuk mendorong badan hukum/pengusaha dengan biaya mandiri melakukan vaksinasi kepada pekerjanya. Dengan demikian pekerja dapat memperoleh vaksinasi gratis karena biaya ditanggung oleh badan hukum/pengusaha.

Terkait dengan upaya pemerintah untuk mempercepat vaksinasi, terjadi pro dan kontra pada masyarakat tak terkecuali pada pekerja industri. Sebagian masyarakat yang menolak vaksinasi memiliki beberapa pendapat diantaranya masih mempermasalahkan halal haramnya kandungan yang terdapat dalam vaksin, hingga pada efektivitas vaksin tersebut serta efek samping setelah vaksin. Hal ini semakin didukung dengan menyebarnya hoaks seperti vaksin memiliki alat pelacak (chip), sampai pada dapat menyebabkan kematian. Hoaks semacam ini mempengaruhi pola pikir masyarakat sehingga membuat mereka takut divaksin (Asri Octafia, 2021).

Tulisan ini membahas perihal analisis hukum bagi pekerja yang menolak vaksinasi Covid19, serta bagaimana peran badan hukum/pengusaha terkait adanya pekerja yang menolak untuk divaksinasi. Sebelumnya sudah ada beberapa tulisan terkait dengan penanggulangan pandemi Covid-19 diantaranya adalah tulisan dari Farina Gandryani dengan judul Pelaksanaan Vaksinasi Covid-19 di Indonesia: Hak atau Kewajiban Warga Negara, menyimpulkan bahwa vaksinasi dalam rangka penanganan Covid-19 adalah suatu hak sekaligus kewajiban dari warga negara. Adapun terkait sanksi pidana dalam pemberlakuan kewajiban vaksinasi seyogyanya tetap 
menjadi suatu sarana terakhir (ultimum remedium) apabila pranata lain tidak berfungsi (Gandryani \& Hadi, 2021).

Tulisan Marulak Pardede dengan judul Aspek Hukum Kekarantinaan Kesehatan dan Perlindungan Konsumen Dalam Penanggulangan Pandemi Covid-19 (Legal Aspects of Health Quarantine and Consumer Protection in Treatment of Covid-19 Pandemic) yang menyimpulkan bahwa eksistensi keberadaan berbagai peraturan perundangan terkait penanggulangan Covid-19 saling berbenturan satu sama lain, terjadi disharmonisasi baik secara horizontal maupun vertikal. Hal ini menunjukkan dalam penyusunan regulasi perundangan belum memperhatikan teori, landasan, asas-asas pembentukan peraturan perundangan sebagaimana diatur dalam UU No. 12 Tahun 2011 juncto UU No. 15 Tahun 2019 Tentang Pembentukan Peraturan PerundangUndangan (Pardede, 2021).

Literasi berbeda tulisan Theresia Louize Pesulima, dan Yosia Hetharie dengan judul Perlindungan Hukum Terhadap Keselamatan Kerja Bagi Tenaga Kesehatan Akibat Pandemi Covid-19 menyimpulkan bahwa perlindungan hukum terhadap keselamatan kerja tenaga kesehatan akibat pandemi Covid-19 belum dapat dilaksanakan dengan baik sebagaimana yang diamanatkan dalam peraturan perundang-undangan, dalam pelaksanaannya hak tenaga kesehatan masih terabaikan dan belum terpenuhi (Pesulima \& Hetharie, 2020). Siti Nurhalimah dengan tulisan berjudul Covid-19 dan Hak Masyarakat atas Kesehatan tulisannya fokus kepada peran pemerintah dalam menjamin hak kesehatan masyarakat pada masa pandemi Covid-19. Kesimpulan dari penelitian ini bahwa pemerintah terlalu lamban dalam mengambil tindakan antisipatif maupun mitigasi dalam menanggulangi pandemi corona. Pada akhirnya pemerintah memilih Pembatasan Sosial Berskala Besar (PSBB) sebagai tindakan merespon status darurat kesehatan masyarakat, sembari tetap memperhatikan sektor ekonomi, dan fiskal sesuai kondisi dan kemampuan negara (Nurhalimah, 2020)

Dalam penelitian Muhamad Beni Kurniawan dengan judul Politik Hukum Pemerintah Dalam Penanganan Pandemi Covid-19 Ditinjau Dari Perspektif Hak Asasi Atas Kesehatan (Government Legal Politics In Handling of Covid-19 Pandemic Reviewed From The Right to Health's Perspective) menyimpulkan bahwa hak asasi atas kesehatan merupakan salah satu derivasi dari hak asasi manusia, politik hukum yang dipilih pemerintah Indonesia berupa PSBB dan physical distancing dalam penanganan Covid-19 belum maksimal dalam melindungi hak kesehatan masyarakat Indonesia sebagaimana diamanatkan oleh ketentuan Pasal 28H ayat (1) dan Pasal 34 ayat (2) serta ayat (3) UUD NRI Tahun 1945 (Kurniawan, 2021).

Berdasarkan latar belakang di atas, perbedaan dan uniknya penulisan ini dibandingkan dengan penelitian-penelitian sebelumnya adalah kajian ini fokus pada bagaimana regulasi perundangan dalam mengatur hak dan kewajiban vaksinasi masyarakat Indonesia secara umum dan kemudian fokus pada program vaksinasi gotong royong yang diupayakan pemerintah agar tercipta percepatan vaksinasi pada sektor pekerja khususnya industri yang merupakan salah satu penopang perekonomian nasional. Penulisan ini juga mengkaji bagaimana peran pengusaha jika terdapat pekerjanya yang tidak mau divaksinasi, serta bagaimana regulasi perundangan ketenagakerjaan mengatur hal ini dalam rangka menyukseskan penanggulangan pandemi Covid19 di Indonesia. Pada penulisan ini terdapat dua hal yang perlu dikaji yaitu pertama, bagaimana analisis hukum bagi pekerja yang menolak vaksinasi Covid-19 di Indonesia; kedua, apakah sanksi yang dapat diberikan badan hukum/pengusaha kepada pekerjanya yang menolak vaksinasi Covid-19.

\section{B. Pembahasan}

\section{Analisis Hukum Bagi Pekerja yang Menolak Vaksinasi Covid-19 di Indonesia}

Pasal 1 angka 1 UU No. 36 Tahun 2009 Tentang Kesehatan menentukan kesehatan adalah keadaan sehat, baik secara fisik, mental, spiritual, maupun sosial yang memungkinkan setiap 
orang untuk hidup produktif secara sosial dan ekonomis. Tanpa adanya kesehatan seorang manusia tidak akan mampu memperoleh hak-haknya yang lain. Oleh karena itu kesehatan dijadikan menjadi salah satu ukuran selain tingkat pendidikan, dan ekonomi, yang menentukan mutu dari sumber daya manusia (Afandi, 2008).

Terkait dengan hak atas kesehatan secara konstitusional dilindungi dalam Pasal 28H ayat (1) UUD NRI Tahun 1945 yang mengatur bahwa, "Setiap orang berhak hidup sejahtera lahir dan batin, bertempat tinggal, dan mendapatkan lingkungan hidup yang baik dan sehat serta berhak memperoleh pelayanan kesehatan”. Berkaitan dengan hak asasi manusia tentang kesehatan, negara memiliki kewajiban untuk memenuhi hak tersebut sebagaimana diatur dalam Pasal 34 ayat (3) UUD NRI Tahun 1945 yang menentukan bahwa, "Negara bertanggung jawab atas penyediaan fasilitas pelayanan kesehatan dan fasilitas pelayanan umum yang layak".

Pemerintah telah mengambil langkah-langkah taktis dalam rangka melindungi kesehatan warga negara dari pandemi Covid-19, mulai dari menetapkan status darurat kesehatan melalui Keputusan Presiden No. 11 Tahun 2020 Tentang Penetapan Kedaruratan Kesehatan Masyarakat Corona Virus Disease 2019 (Covid-19), membangun rumah sakit darurat, melakukan program 3T (testing, tracing, treatment), sampai melakukan pembatasan wilayah dengan diterbitkannya Peraturan Pemerintah No. 21 Tahun 2020 Tentang Pembatasan Sosial Berskala Besar Dalam Rangka Percepatan Penanganan Corona Virus Disease 2019 (Covid-19). Upaya lain yang dilakukan pemerintah adalah membentuk kekebalan kelompok pada masyarakat (herd immunity) melalui program vaksinasi yang dimulai pada bulan Januari 2021. Pelaksanaan vaksinasi ini mendapatkan banyak respon dari masyarakat baik yang pro maupun kontra. Masyarakat yang kontra masih meragukan beberapa hal seperti bagaimana halal dan haramnya kandungan vaksin, sampai pada bagaimana efek samping dari vaksinasi. Sebagian kalangan aktivis juga menyuarakan bahwasanya menolak vaksin adalah hak asasi rakyat, sehingga negara tidak dapat memaksakan agar semua warga negara menerima vaksinasi.

Menurut regulasi perundangan yang berlaku, adanya pernyataan bahwa menolak vaksinasi adalah hak warga negara, diatur pada Pasal 5 ayat (3) UU No. 36 Tahun 2009 Tentang Kesehatan yang mengatur bahwa, "Setiap orang berhak secara mandiri dan bertanggung jawab menentukan sendiri pelayanan kesehatan yang diperlukan bagi dirinya". Namun jika dikaji dengan melihat kondisi di Indonesia bahkan masyarakat internasional saat ini dengan adanya pandemi Covid-19, pelaksanaan vaksinasi merupakan sesuatu yang bersifat wajib. Landasan hukum yang dapat menjadi dasar bahwa vaksinasi pada masa pandemi Covid-19 merupakan kewajiban dapat kita lihat pada beberapa regulasi seperti Pasal 14 ayat (1) UU No. 4 Tahun 1984 Tentang Wabah Penyakit Menular yang mengatur bahwa, "Barang siapa dengan sengaja menghalangi pelaksanaan penanggulangan wabah sebagaimana diatur dalam undang-undang ini, diancam dengan pidana penjara selama-lamanya 1 (satu) tahun dan/atau denda setinggi-tingginya Rp 1.000.000,00 (satu juta rupiah)".

Selanjutnya Pasal 93 UU No. 6 Tahun 2018 Tentang Kekarantinaan Kesehatan yang mengatur:

"Setiap orang yang tidak mematuhi penyelenggaraan kekarantinaan kesehatan sebagaimana dimaksud dalam Pasal 9 ayat (1) dan/atau menghalang-halangi penyelenggaraan kekarantinaan kesehatan sehingga menyebabkan kedaruratan kesehatan masyarakat dipidana dengan pidana penjara paling lama 1 (satu) tahun dan/atau pidana denda paling banyak Rp 100.000.000,00 (seratus juta rupiah)".

Sedangkan Pasal 9 UU No. 6 Tahun 2018 Tentang Kekarantinaan Kesehatan menentukan bahwa,"(1) Setiap orang wajib mematuhi penyelenggaraan kekarantinaan kesehatan; (2) Setiap orang berkewajiban ikut serta dalam penyelenggaraan kekarantinaan kesehatan".

Terhadap wilayah yang menerapkan Pembatasan Sosial Berskala Besar (PSBB), maka diberlakukan ketentuan Pasal 93 UU No. 6 Tahun 2018 Tentang Kekarantinaan Kesehatan, sedangkan pada wilayah yang tidak menerapkan PSBB peraturan yang digunakan adalah Pasal 
14 ayat (1) UU No. 4 Tahun 1984 Tentang Wabah Penyakit Menular. Dengan demikian setelah adanya Keputusan Presiden No. 11 Tahun 2020 Tentang Penetapan Kedaruratan Kesehatan Masyarakat Corona Virus Disease 2019 (Covid-19), serta vaksinasi (sementara saat ini) dianggap merupakan cara terbaik dalam rangka untuk menanggulangi Covid-19, maka ketentuan UU No. 36 Tahun 2009 Tentang Kesehatan dapat dikesampingkan dan yang berlaku adalah UU No. 6 Tahun 2018 Tentang Kekarantinaan Kesehatan \& UU No. 4 Tahun 1984 Tentang Wabah Penyakit Menular. Sehingga dalam konteks ini vaksinasi menjadi bersifat wajib dan barangsiapa menghalang-halangi serta menolak upaya dalam rangka memutus rantai penularan Covid-19, maka orang tersebut dapat dikenakan sanksi.

Saat ini pemerintah telah mengumumkan bahwa negara dalam keadaan darurat, maka berlaku asas salus populi suprema lex yang berarti keselamatan rakyat adalah hukum yang tertinggi. Hal senada juga disampaikan oleh Mahfud MD yang berpendapat bahwa keselamatan rakyat lebih tinggi daripada UUD (Mahfud M.D., 2010). Clement Fatovic menyebutkan bahwa, "Exercise of prerogative by the executive are constitutionally permissible as long as these activities do not conflict with the fundamental substantive principle of natural law: salus populi suprema lex, "the welfare of the people is the supreme law" (Santoso, 2017). Vaksinasi yang dilakukan oleh pemerintah tersebut adalah untuk menyelamatkan masyarakat Indonesia itu sendiri.

Analisis selanjutnya adalah Pasal 5 ayat (3) UU No. 36 Tahun 2009 Tentang Kesehatan, memang memberikan hak terhadap setiap orang untuk dapat menentukan pelayanan kesehatan yang dibutuhkan untuk dirinya sendiri, bahkan pasal ini sesuai dengan landasan konstitusional pada ketentuan Pasal 28H ayat (1) UUD NRI Tahun 1945. Meskipun demikian harus dipahami bahwa hak asasi seseorang sesungguhnya dibatasi juga dengan adanya hak asasi orang lain, hal ini sesuai dalam ketentuan Pasal 28J UUD NRI Tahun 1945.

Menurut Mahfud MD, bahwa dalam menggunakan hak dan kebebasan konstitusional, harus juga disertai dengan kesadaran akan kewajiban dan tanggung jawab konstitusional untuk menghormati hak dan kebebasan orang lain. Jika terdapat benturan pada kebebasan yang diperjuangkan dengan hak dan kebebasan orang lain, maka yang dicari adalah kebenaran substansial dan keadilan (Mahfud MD, 2006). Seseorang yang menolak dan tidak bersedia divaksin dapat berpotensi menjadi pembawa virus bagi orang lain, karena tidak menutup kemungkinan sebenarnya orang tersebut sudah terpapar Covid-19 namun karena memiliki imun yang kuat sehingga kesehatannya tidak terganggu. Namun hal tersebut dapat mengancam nyawa orang lain yang kebetulan tidak memiliki imun sekuat orang yang menolak vaksinasi tersebut. Sebenarnya vaksinasi tidak hanya bermaksud untuk melindungi diri sendiri, namun juga untuk melindungi orang lain agar dapat menciptakan kekebalan komunitas (herd immunity), sehingga dengan melihat tujuan yang demikian seharusnya vaksinasi ini tidak ditolak (Handayani وآ 2020).

Setiap orang yang telah ditetapkan sebagai sasaran penerima vaksin Covid-19 dan menolak vaksinasi Covid-19 menurut ketentuan Pasal 13A ayat (4) Peraturan Presiden No. 14 Tahun 2021 Tentang Perubahan Atas Peraturan Presiden No. 99 Tahun 2020 Tentang Pengadaan Vaksin dan Pelaksanaan Vaksinasi Dalam Rangka Penanggulangan Pandemi Corona Virus Disease 2019 (Covid-19) dapat dikenakan sanksi berupa tiga hal meliputi penundaan atau penghentian pemberian jaminan sosial atau bantuan sosial, penundaan atau penghentian layanan administrasi pemerintahan, dan denda. Pengenaan sanksi tersebut dilakukan oleh kementerian, lembaga, pemerintah daerah, atau badan sesuai kewenangannya (Rahman, 2021).

Agar supaya perekonomian pada masa pandemi Covid-19 dapat terus berjalan dan tidak semakin terpuruk, maka pekerja harus mendapatkan prioritas perlindungan dari resiko virus Covid-19. Salah satu bentuk ikhtiar pemerintah adalah dengan mekanisme vaksin gotong royong.

Vaksinasi gotong royong sesuai dengan ketentuan Pasal 1 angka 5 Peraturan Menteri Kesehatan No. 19 Tahun 2021 Tentang Perubahan Kedua Atas Peraturan Menteri Kesehatan No. 
10 Tahun 2021 Tentang Pelaksanaan Vaksinasi Dalam Rangka Penanggulangan Pandemi Corona Virus Disease 2019 (Covid-19) diberikan secara gratis kepada pekerja beserta keluarganya sehingga tidak ada istilah pekerja wajib membayar ataupun potong gaji karena yang menanggung adalah perusahaan. Vaksinasi gotong royong ini merupakan upaya pemerintah untuk menanggung beban biaya vaksin bersama-sama dengan badan hukum perusahaan/pengusaha agar bisa terjadi percepatan pelaksanaan vaksinasi dengan harapan agar segera tercipta herd immunity. (Danurahman \& Kusdarini, 2021).

Sejak adanya revolusi industri 4.0 Indonesia merupakan salah satu negara yang turut melakukan evaluasi dalam rangka untuk meningkatkan kualitas dan produktivitasnya dalam bidang jasa, industri, dan perdagangan agar dapat bersaing di kancah dunia (Akbar, 2020). Percepatan vaksinasi pada masa pandemi Covid-19 melalui vaksinasi gotong royong diharapkan dapat meminimalisir pekerja terpapar Covid-19 sehingga kesehatan pekerja dapat mendukung produktifitas produksi barang dan jasa.

\section{Sanksi yang Dapat Diberikan Badan Hukum/Pengusaha kepada Pekerjanya yang Menolak Vaksinasi Covid-19}

Hubungan kerja antara pengusaha dan pekerja yang berada di dalam suatu perusahaan terjadi setelah adanya suatu perjanjian kerja antara pekerja dengan pengusaha. Dengan adanya perjanjian kerja, maka timbul kewajiban satu pihak untuk bekerja pada pihak lainnya. Bekerja pada pihak lainnya, menunjukkan bahwa pada umumnya hubungan itu sifatnya ialah bekerja di bawah pimpinan pihak lain (Pohan, 2020).

Menurut Erlyn Indarti, keadilan dipahami secara berbeda-beda sesuai dengan paradigma yang dianut, berdasarkan paradigma konstruktivisme keadilan bagi masyarakat dapat terjamin tatkala kemerdekaan setiap anggota masyarakat secara aktif mengkonstruksi hukum untuk kemudian mewujudkan resultane konstruksi hukum atau mencapai konsensus atau kesepakatan melalui proses demokrasi (Farianto, 2019). Terkait dengan program percepatan vaksinasi ini, keadilan sosial dapat terselenggara apabila pemerintah menjalankan perannya, warga masyarakat mentaatinya dan antar warga saling berimbal balik dalam memberikan hak dan kewajiban. Dalam kaitannya dengan penanggulangan pandemi Covid-19 khususnya pada sektor industri, hubungan kerja antara pekerja dan pengusaha wajib mentaati aturan dan saling timbal balik sehingga terjadi keseimbangan. Pekerja dengan pengusaha harus menciptakan hubungan kerja yang harmonis, sehingga tujuan kesejahteraan pekerja dan keluarganya dapat terselenggara dengan tetap memperhatikan kepentingan dunia usaha (Aisha, 2019).

Vaksinasi gotong royong lebih lanjut diatur dalam Peraturan Menteri Kesehatan No. 19 Tahun 2021 Tentang Perubahan Kedua Atas Peraturan Menteri Kesehatan No. 10 Tahun 2021 Tentang Pelaksanaan Vaksinasi Dalam Rangka Penanggulangan Pandemi Corona Virus Disease 2019 (Covid-19). Pada ketentuan Pasal 5 ayat (3) mengatur bahwa karyawan/karyawati, keluarga, dan individu lain terkait dalam keluarga, dan individu/orang sebagai penerima vaksinasi Covid-19 dalam pelaksanaan vaksinasi gotong royong tidak dipungut biaya dan ditanggung oleh badan hukum/pengusaha. Dengan adanya kemudahan pekerja untuk mendapatkan vaksinasi Covid-19 seperti ini diharapkan herd immunity pada lingkungan kerja segera tercipta dan meminimalisir tingginya paparan Covid-19 di lingkungan kerja. Hal ini akan membawa dampak positif pada produktivitas perusahaan, sehingga akan memperkuat kondisi perusahaan dan meminimalisir PHK.

Terkait dengan sanksi bagi pekerja sebagai bagian dari warga negara yang menolak vaksinasi Covid-19 sudah dibahas pada sub bab sebelumnya, namun terkait statusnya sebagai pekerja pada perusahaan badan hukum, ketentuan dalam regulasi perundangan ketenagakerjaan bahwa selama dalam perjanjian kerja, peraturan perusahaan (PP)/ perjanjian kerja bersama (PKB) tidak mengatur penolakan vaksinasi Covid-19 sebagai pelanggaran maka sanksi tidak dapat diberikan. Disinilah peran pengusaha agar segera memberikan edukasi kepada semua 
pekerjanya perihal manfaat dan resiko kesehatan jika tidak divaksinasi Covid-19, sehingga pekerja paham dan dapat serentak melakukan vaksinasi Covid-19 dengan penuh kesadaran.

Pekerja yang tidak mau divaksinasi, kecuali karena adanya komorbit/sesuatu yang dikecualikan untuk divaksinasi Covid-19 dapat dikenakan sanksi administrasi sesuai ketentuan Pasal 13A ayat (4) Peraturan Presiden No. 14 Tahun 2021 yang mengatur bahwa, jika seseorang telah ditetapkan sebagai sasaran penerima vaksin Covid-19 kemudian tidak melaksanakan vaksinasi maka akan dikenai sanksi administratif berupa penundaan atau penghentian pemberian jaminan sosial atau bantuan sosial, penundaan atau penghentian layanan administrasi pemerintahan, dan/atau denda. Pengusaha dapat memberikan sanksi kepada pekerja akibat adanya pekerja yang tidak melaksanakan vaksinasi Covid-19 sehingga mengakibatkan pekerja tersebut dapat terhambat peran dan fungsinya dalam melakukan pekerjaan sesuai kewajibannya di perusahaan.

Pekerja dapat di-PHK oleh pengusaha jika pekerja tersebut tidak dapat melakukan pekerjaan selama 6 bulan akibat ditahan pihak yang berwajib karena diduga melakukan tindak pidana akibat menolak vaksinasi Covid-19 sesuai dengan ketentuan Pasal 9 ayat (1) jo Pasal 93 UU No. 6 Tahun 2018 Tentang Kekarantinaan Kesehatan dengan ancaman pidana 1 tahun dan/atau denda maksimal 100 juta Rupiah. Ketentuan ini diatur pada Pasal 81 angka 42 UU No. 11 Tahun 2020 Tentang Cipta Kerja yang memuat ketentuan baru Pasal 154A ayat (1) dan (2) UU No. 13 Tahun 2003 Tentang Ketenagakerjaan yang menentukan bahwa alasan PHK yaitu: a. Pekerja melakukan pelanggaran ketentuan yang diatur dalam perjanjian kerja, PP atau PKB dan sebelumnya telah diberikan surat peringatan pertama, kedua, dan ketiga secara berturut-turut masing-masing berlaku untuk maksimal 6 bulan, kecuali ditetapkan lain dalam perjanjian kerja, PP, atau PKB; b. Pekerja tidak dapat melakukan pekerjaan selama 6 bulan akibat ditahan pihak yang berwajib karena diduga melakukan tindak pidana; c. Alasan PHK lainnya sebagaimana diatur dalam perjanjian kerja, PP, atau PKB.

Berkaitan dengan ketentuan regulasi di atas, maka pengusaha dapat membuat adendum yang mengatur kewajiban pekerja melaksanakan vaksinasi Covid-19 dari PP/PKB dimana adendum tersebut merupakan satu kesatuan dari PP/PKB dan memiliki kekuatan hukum yang sama. Setelah adanya adendum tersebut, maka pengusaha dapat memberikan sanksi jika ada pekerja yang menolak vaksinasi Covid-19.

\section{Simpulan}

Vaksinasi dalam kondisi status darurat pandemi Covid-19 merupakan kewajiban bagi semua warga negara, bahkan bagi siapa yang dengan sengaja hendak menghalangi pelaksanaan penanggulangan wabah ini dapat diancam dengan pidana penjara dan/atau denda. Vaksinasi Gotong Royong merupakan ikhtiar dari pemerintah untuk mempercepat vaksinasi pada pekerja klaster industri dan jasa, dimana biaya ditanggung oleh pengusaha/badan hukum perusahaan.

Pekerja yang menolak vaksinasi Covid-19 tidak serta merta dapat diberikan sanksi apabila dalam perjanjian kerja ataupun $\mathrm{PP} / \mathrm{PKB}$ belum mengatur perihal vaksinasi Covid-19. Peran pengusaha disini diperlukan untuk dapat memberikan edukasi dan pemahaman kepada semua pekerja perihal hal ikhwal vaksinasi Covid-19, sehingga diharapkan pekerja dapat memahami secara utuh dan benar serta dapat mendukung pelaksanakan vaksinasi Covid-19 di lingkungan kerja. Perkembangan saat ini apabila warga negara tidak mau vaksinasi Covid-19 maka akan mendapatkan sanksi administratif dari pemerintah antara lain penundaan/penghentian pemberian jaminan sosial, penundaan/penghentian layanan administrasi pemerintahan, dan/atau denda. Bagi pekerja, hal ini tentu dapat mengganggu efektivitas dalam menjalankan tugas pekerjaan dalam perusahaan. Pekerja dapat di-PHK oleh pengusaha apabila tidak dapat bekerja 6 bulan akibat ditahan pihak berwajib karena dugaan melakukan tindak pidana akibat menolak vaksinasi Covid19 sesuai dengan peraturan yang berlaku. Untuk mendukung program pemerintah dalam menanggulangi pandemi Covid-19 pengusaha dapat membuat adendum pada PP/PKB yang 
mengatur perihal kewajiban pekerja melaksanakan vaksinasi Covid-19 lengkap beserta sanksi apabila karyawan menolak vaksinasi Covid-19.

\section{DAFTAR PUSTAKA}

Acikgoz, O., \& Gunay, A. (2020). The Early Impact of The Covid-19 Pandemic on the Global and Turkish Economy. Turkish Journal of Medical Sciences, 50(3), 520-526.

Afandi, D. (2008). Hak Atas Kesehatan Dalam Perspektif HAM. Jurnal Ilmu Kedokteran, 2(1), $1-6$.

Aisha, B. D. (2019). Pemutusan Hubungan Kerja yang Didasarkan Pada Pelanggaran Perjanjian Kerja Bersama. Jurist Diction Law Journal, 2(1), 63-76.

Akbar, J. H. (2020). Politik Hukum Pengaturan Pegawai Pengawas Ketenagakerjaan Guna Meningkatkan Kualitas Ketenagakerjaan di Era Industri 4.0. Jurnal Hukum Progresif, 8(2), 167-182. https://doi.org/10.14710/jhp.8.2.167-182

Asri Octafia, L. (2021). Vaksin Covid-19: Perdebatan, Persepsi dan Pilihan. Emik, 4(2), 160 174. https://doi.org/https://doi.org/10.46918/emik.v4i2

Danurahman, J., \& Kusdarini, E. (2021). Dampak Pandemi Coronavirus Disease (Covid-19) Dalam Perspektif Hukum Di Era Digital. Masalah-Masalah Hukum, 50(2), 151-160. https://doi.org/10.14710/mmh.50.2.2021.151-160

Farianto, W. (2019). Pola Hubungan Hukum Pemberi Kerja dan Pekerja (Hubungan Kerja Kemitraan \& Keagenan) (M. Sari (محرد)). Sinar Grafika.

Gandryani, F., \& Hadi, F. (2021). Pelaksanaan Vaksinasi Covid-19 Di Indonesia: Hak Atau Kewajiban Warga Negara (The Vaccination of Covid-19 in Indonesia:Citizen Right or Citizen Duty). Jurnal Rechts Vinding: Media Pembinaan Hukum Nasional, 10(1), 23-41.

Guan, D., Wang, D., Li, S., \& Xue, Q. (2020). Global supply-chain effects of COVID-19 control measures. Nature Human Behaviour, 4, 577-587.

Handayani, R. T., Arradini, D., Widiyanto, A., \& Atmojo, J. T. (2020). Pandemic Covid-19, Body Immunity Response, and Herd Immunity. Jurnal Ilmiah PERMAS: Jurnal Ilmiah STIKES Kendal, 10(3), 373-380.

Kurniawan, M. B. (2021). Politik Hukum Pemerintah Dalam Penanganan Pandemi Covid-19 Ditinjau Dari Perspektif Hak Asasi Atas Kesehatan (Government Legal Politics in Handling of Covid-19 Pandemic Reviewed From The Right To Health's Perspective). Jurnal Ham, 12(1), 37-55.

Mahfud M.D., M. (2010). Konstitusi dan Hukum dalam Kontroversi Isu. Rajawali Pers.

Mahfud MD, M. (2006). Membangun Politik Hukum, Menegakkan Konstitusi. LP3ES.

Nurhalimah, S. (2020). Covid-19 dan Hak Masyarakat atas Kesehatan. SALAM: Jurnal Sosial dan Budaya Syar-i, 7(6), 543-554. https://doi.org/10.15408/sjsbs.v7i6.15324

Ozili, P. K., \& Arun, T. G. (2020). Spillover of COVID-19: impact on the Global Economy. SSRN Electronic Journal. https://doi.org/10.2139/ssrn.3562570

Pardede, M. (2021). Aspek Hukum Kekarantinaan Kesehatan dan Perlindungan Konsumen dalam Penanggulangan Pandemi Covid-19. Jurnal Penelitian Hukum De Jure, 21(1), 23. https://doi.org/10.30641/dejure.2021.v21.23-44 
Pesulima, T. L., \& Hetharie, Y. (2020). Perlindungan Hukum Terhadap Keselamatan Kerja Bagi Tenaga Kesehatan Akibat Pandemi Covid-19. SASI, 26(2), 280-285.

Pohan, M. R. (2020). Perlindungan Hukum Terhadap Pekerja Dalam Perjanjian Kerja Waktu Tertentu: Menurut Hukum Ketenagakerjaan. MLJ Merdeka Law Journal, 1(2), 60-71.

Rahman, Y. A. (2021). Vaksinasi Massal Covid-19 sebagai Sebuah Upaya Masyarakat dalam Melaksanakan Kepatuhan Hukum (Obedience Law). Khazanah Hukum, 3(2), 80-86. https://doi.org/10.15575/kh.v3i2.11520

Rothan, H. A., \& Byrareddy, S. N. (2020). The epidemiology and pathogenesis of coronavirus disease (COVID-19) outbreak. Journal of Autoimmunity, 109. https://doi.org/10.1016/j.jaut.2020.102433

Santoso, B. T. (2017). Pemberian Grasi Oleh Presiden Bagi Terpidana Antasari Azhar. Mimbar Yustitia, 1(1), 1-20. 